\title{
PENGARUH KODE ETIK, KOMPETENSI, DAN PENGALAMAN TERHADAP SKEPTISME PROFESIONAL AUDITOR (STUDI KASUS PADA INSPEKTORAT PROVINSI BENGKULU)
}

\author{
Asmil Darafni \\ Fadli \\ Praningrum \\ Program Studi Manajemen Fakultas Ekonomi dan Bisnis Universitas Bengkulu
}

\begin{abstract}
The purpose of this research is to know the influence of ethical code; competency and experience towards professional sceptic of auditors in the Inspectorate Office of Bengkulu Province by simultaneously and partially. The sample in this research are auditors of Inspectorate Office of Bengkulu Province taken usingcensus method. The number of respondents are 46 respondents. The method of the data analysis used was multiple regression analysis. The results from the data analysis show that: (1) the ethical code; competency and experience have positive and significant influence towardsprofessional sceptic of auditors at the Inspectorate of Bengkulu Province; (2) the ethical code have positive and significant influence towardsprofessional sceptic of auditors at the Inspectorate of Bengkulu Province; (3) the competency have positive and significant influence towardsprofessional sceptic of auditors at the Inspectorate of Bengkulu Province; and (4) the experience have positive and significant influence towardsprofessional sceptic of auditors at the Inspectorate of Bengkulu Province. Its mean if the ethical code, competency and experience have increasing, the professional sceptic of auditors at the Inspectorate of Bengkulu Province will be higher.
\end{abstract}

Keywords: Ethical code; Competence; Experience; and Professional sceptic.

\section{PENDAHULUAN}

\section{Latar Belakang}

Tuntutan masyarakat akan penyelenggaraan pemerintah yang bersih dan bebas korupsi, kolusi, dan nepotisme (KKN) menghendaki adanya pelaksanaan fungsi pengawasan dan sistem pengendalian intern yang baik atas pelaksanaan pemerintahan dan pengelolaan keuangan Negara. Pedoman yang dapat memberi menjamin bahwa pelaksanaan kegiatan telah sesuai dengan kebijakan dan rencana yang telah ditetapkan serta untuk menjamin tujuan tercapai secara hemat, efisien, dan efektif.

Peran auditor dalam mengawasi pelaksanaan anggaran sangatlah penting. Salah satu bentuk pengawasan yang sangat penting perannya adalah pengawasan intern 
pemerintah. Melalui pengawasan intern dapat diketahui apakah suatu instansi pemerintah telah melaksanakan kegiatan sesuai dengan tugas dan fungsinya secara efektif dan efisien, serta sesuai dengan rencana, kebijakan dan ketentuan yang telah ditetapkan. Selain itu, pengawasan intern atas penyelenggaraan pemerintahan diperlukan untuk mendorong terwujudnya good governance dan clean government dan mendukung penyelenggaraan pemerintahan yang efektif, efisien, transparan, akuntabel serta bersih dan bebas dari praktik korupsi, kolusi, dan nepotisme (Permenpan Nomor: 19 Tahun 2009).

Auditor adalah pegawai negeri sipil (PNS) yang mempunyai jabatan fungsional auditor dan atau pihak lain yang diberi tugas, wewenang, tanggungjawab dan hak secara penuh oleh pejabat berwenang. Tugas yang dilaksanakan merupakan tugas pengawasan terhadap instansi pemerintah untuk dan atas nama aparat pengawas (Permenpan No: PER/05/M/PAN/03/2008).

Salah satu sikap yang penting dimiliki seorang auditor adalah skeptis. Skeptisme bukan berarti tidak percaya, tapi mencari pembuktian sebelum dapat menerima suatu pernyataan atau laporan (Louwers dkk, 2008). Sikap skeptisme profesional akan membawa auditor pada tindakan untuk memilih prosedur audit yang efektif sehingga diperoleh hasil audit yang tepat (Noviyanti, 2008).

Pada kenyataannya sikap skeptisme yang dimiliki oleh auditor akan berdampak negatif terhadap audit. Dari hasil pengamatan awal yang dilakukan dengan mewawancarai 3 orang bendahara pada SKPD atau Dinas yang merupakan objek pemeriksaan Inspektorat Provinsi Bengkulu, bahwa sikap skeptisme auditor berdampak negatif terhadap para pegawai (PNS) atau auditi seperti fenomena sebagai berikut:

Informan 1 memberikan jawaban :

"Menurut saya auditor inspektorat bersedia diajak kompromi dalam pelaksanaan audit"

Informan 2 memberikan jawaban:

"Saya rasa auditor kurang ramah, terlihat angkuh dan bersikap cuek...padahal kami sudah berupaya kooperatif dalam kegiatan pemeriksaan"

Informan 3 menjawab:

"Menurut saya auditor inspektorat terlihat berlebihan dalam pelaksanaan audit, kadang-kadang bersikap tidak bersahabat...namun tidak semuanya.."

Dari pengakuan informan tersebut di tataran empiris terlihat sikap-sikap negatif yang ditunjukkan oleh auditor berdampak pada auditi seperti fenomena sebagai berikut:

$>$ Menurunnya produktivitas pegawai terutama bagi pegawai yang memegang kegiatan atau bendahara.

$>$ Tertundanya pekerjaan yang lain dikarenakan masih dalam proses pelayanan terhadap pemeriksaan yang dilakukan oleh auditor.

$>$ Menimbulkan tingkat setres yang tinggi pada pegawai atau auditi

$>$ Keengganan dinas (auditi) untuk di periksa oleh auditor. 
$>$ Dapat menghambat proses kegiatan yang akan dilakukan oleh masing-masing dinas (auditi) karena terfokus pada kegiatan pemeriksaan oleh auditor.

Skeptisme auditor juga akan menimbulkan dampak negatif terhadap auditor itu sendiri didalam pekerjaannya seperti sebagai berikut:

$>$ Ketepatan waktu dalam penyusunan laporan audit menjadi kurang tepat karena masih menunggu bukti pendukung lain yang di anggap akurat.

$>$ Kurang menguasai atau memahami topik yang diperiksa.

$>$ Ketidakterbukaan auditi dalam pemeriksaan yang di lakukan oleh auditor.

$>$ Audit Internal hanya buang waktu tidak ada efek yang berarti, tidak seperti halnya audit dari Exsternal.

$>$ kurangnya respon dari Pimpinan (atasan) prioritas utama hanya kegiatan audit harus jalan.

Dampak lain dari perilaku skeptisme auditor Kantor Inspektorat Provinsi Bengkulu ada pada hasil pengawasan yang dilakukan oleh auditor. Hal tersebut terbukti dari ditemukannya kasus pengelolaan anggaran yang tidak sesuai dengan ketentuan, yang luput dari pengawasan auditor internal sebagai APIP. Kasus tersebut mencuat pada Tahun 2013, yakni penyaluran dana APBD sebesar Rp 26.02 miliar pada beberapa SKPD Provinsi Bengkulu, yang tidak di sertai Naskah Perjanjian Hibah Daerah (NPHD) dan bahkan ada yang fiktif (Rakyat Bengkulu, Februari 2013).

Temuan ini menggambarkan bahwa pengelolaan keuangan daerah dan pengawasan keuangan di Provinsi Bengkulu masih harus banyak dilakukan perbaikan. Oleh karena itu, tentu saja tidak berlebihan jika sebagai pengelola keuangan daerah dan pengawas keuangan (auditor) harus memiliki keahlian dalam bidang akuntansi sangat dibutuhkan, sehingga nantinya akan menghasilkan informasi keuangan daerah yang relevan dan handal sebagaimana dipersyaratkan dalam kualitas laporan keuangan dan kualitas audit.

Peran dan fungsi Inspektorat Provinsi Bengkulu, Kabupaten/Kota secara umum diatur dalam pasal 4 Peraturan Menteri Dalam Negeri No. 64 Tahun 2007. Dalam pasal tersebut dinyatakan bahwa dalam melaksanakan tugas pengawasan urusan pemerintah, Inspektorat Provinsi, Kabupaten/Kota mempunyai fungsi sebagai berikut: pertama, perencanaan program pengawasan; kedua, perumusan kebijakan dan fasilitas pengawasan; ketiga, pemeriksaan, pengusutan, pengujian dan penilain tugas pengawasan. Berkaitan dengan peran dan fungsi tersebut, Inspektorat Provinsi Bengkulu sebagaimana yang diatur dalam Peraturan Gubernur Provinsi Bengkulu Nomor 10 Tahun 2008, mempunyai tugas pokok membantu Kepala Daerah dalam menyelenggarakan Pemerintah Daerah dalam bidang Pengawasan.

Struktur organisasi Inspektorat Provinsi Bengkulu terdiri dari Inspektur, Sekretaris, Inspektur Pembantu Wilayah (Irban), dan kelompok jabatan fungsional. Jabatan fungsional auditor sebanyak 46 orang dan Jabatan Fungsional Pejabat Pengawas Pemerintahan Daerah (P2UPD) sebanyak 24 orang.

Kualitas audit yang dilakukan oleh aparat Inspektorat Provinsi Bengkulu saat ini masih menjadi sorotan. Hasilpra-survey peneliti pada beberapa SKPD menilai 
Inspektorat Provinsi Bengkulu terlalu rumit dan cenderung memberi rasa tidak nyaman dalam melaksanakan kegiatan audit, sebagaimana petikan wawancara dengan Bapak "RD” pada Tanggal 12 April 2016:

"Saya menilai bahwa auditor inspektorat dalam melakukan pengawasan cenderung memberi rasa tidak nyaman...agak kasar dan kurang ramah.."

Selain itu, ada beberapa orang di SKPD lainnya juga beranggapan bahwa Inspektorat terlalu longgar dalam melakukan pemeriksaan dan memberi ruang kecurangan dalam melaksanakan kegiatan penggunaan anggaran pemerintah. Seharusnya auditor inspektorat secara profesional menggunakan kecakapannya untuk balance antara sikap curiga dan sikap percaya.

Skeptisme profesional auditor sering kali tidak sesuai dengan yang diharapkan. Banyak hal yang menyebabkan kondisi tersebut terjadi. Secara umum penyebab utama adalah situasi internal dan eksternal auditor. Kondisi Internal maksudnya perbedaan yang dimiliki oleh masing-masing auditor dalam hal pengalaman dan keahlian. Sedangkan kondisi eksternal sebenarnya tergantung kepada kepatuhan terhadap aturan atau norma yang telah ditetapkan bagi seorang auditor (kode etik).

Kode etik merupakan serangkaian aturan tentang prilaku nilai moral dan normanorma, oleh karena itu kode etik mencakup seluruh etika-etika auditor inspektorat secara jelas. Namun kenyataannya terdapat beberapa auditor yang tidak sepenuhnya mentaati kode etik. Alokasi waktu audit yang singkat, kondisi auditi (rekan, sahabat, keluarga), fee dari auditi dan tekanan dari atasan terkadang menjadikan skeptisme profesional auditor inspektorat Bengkulu menjadi rendah. Disisi lain kemungkinan rendahnya skeptisme profesional auditor juga dapat disebabkan oleh aturan norma dan kode etik yang tidak terlalu jelas sehingga memberi peluang bagi para auditor untuk dapat mengabaikan kode etik tersebut.

\section{KAJIAN PUSTAKA}

\section{Skeptisme Profesional Auditor}

Seorang auditor yang memiliki skeptisme profesional tidak akan menerima begitu saja penjelasan dari klien, tetapi akan mengajukan pertanyaan untuk memperoleh alasan, bukti dan konfirmasi mengenai obyek yang dipermasalahkan. Sikap skeptisme profesional akan membawa auditor pada tindakan untuk memilih prosedur audit yang efektif sehingga diperoleh opini audit yang tepat (Noviyanti, 2008). Skeptisme profesional auditor dapat dipengaruhi oleh beberapa faktor, diantaranya keahlian, pengalaman, situasi audit yang dihadapi, dan etika (Gusti dan Ali, 2008).

Skeptisme, berasal dari kata skeptis, dalam Kamus Besar Bahasa Indonesia (Pusat Bahasa, 2008) dan kamus Oxford (Gusti dan Ali, 2008) berarti sikap meragukan, mencurigai, dan tidak memercayai kebenaran suatu hal, teori, ataupun pernyataan. Dalam buku istilah akuntansi dan auditing, skeptisme berarti bersikap ragu-ragu terhadap pernyataan-pernyataan yang belum cukup kuat dasar-dasar pembuktiannya (Islahuzzaman, 2012). Sedangkan profesional, menurut Kamus 
Besar Bahasa Indonesia (Pusat Bahasa, 2008) adalah sesuatu yang bersangkutan dengan profesi, yang membutuhkan keahlian khusus untuk menerapkannya.

Kata profesional dalam skeptisme profesional merujuk pada fakta bahwa auditor telah, dan terus dididik dan dilatih untuk menerapkan keahliannya dalam mengambil keputusan sesuai standar profesionalnya (Quadackers, 2009). Skeptisme profesional sendiri belum memiliki definisi yang pasti (Islahuzzaman, 2012), namun dari definisi kata skeptisme dan profesional tersebut, dapat disimpulkan bahwa skeptisme profesional auditor adalah sikap auditor yang selalu meragukan dan mempertanyakan segala sesuatu, dan menilai secara kritis bukti audit serta mengambil keputusan audit berlandaskan keahlian auditing yang dimilikinya. Skeptisme bukan berarti tidak percaya, tapi mencari pembuktian sebelum dapat memercayai suatu pernyataan (Louwers dkk, 2008).

Secara khusus dalam audit, Standar Profesional Auditor (IAPI, 2011) menjelaskan bahwa skeptisme profesional adalah sikap yang selalu mempertanyakan dan melakukan evaluasi bukti audit secara kritis. Pengertian serupa dipaparkan dalam International Standards on Auditing (IAASB, 2009), skeptisme profesional adalah sikap yang meliputi pikiran yang selalu bertanyatanya (questioning mind), waspada (alert) terhadap kondisi dan keadaan yang mengindikasikan adanya kemungkinan salah saji material yang disebabkan oleh kesalahan atau kesengajaan (fraud), dan penilaian (assessment) bukti-bukti audit secara kritis. Konsep skeptisme profesional yang tercermin dalam standar tersebut adalah sikap selalu bertanya-tanya, waspada, dan kritis dalam melaksanakan seluruh proses audit.

\section{Kode Etik}

Ciri utama auditor internal adalah kesediaan menerima tanggung jawab terhadap kepentingan pihak-pihak yang dilayani. Dengan demikian tujuan kode etik auditor internal adalah agar dapat membantu tanggung jawab secara efektif, maka Auditor Internal perlu memelihara standar perilaku yang tinggi (No.PER/04/M.PAN/03/2008).

Kode etik ini memuat standar perilaku sebagai pedoman bagi seluruh auditor internal. Standar perilaku tersebut membentuk prinsip-prinsip dasar dalam menjalankan praktik audit internal. Para auditor internal wajib menjalankan tanggung jawab profesinya dengan bijaksana, penuh martabat, dan kehormatan. Dalam menerapkan kode etik auditor ini adalah auditor internal harus memperhatikan peraturan perundang-undangan yang berlaku. Adapun standar perilaku auditor internal adalah sebagai berikut (APIP, 2007):

1. Auditor Internal harus menunjukkan kejujuran, objektivitas, dan kesungguhan dalam melaksanakan tugas dan memenuhi tanggung jawab profesinya;

2. Auditor internal harus menunjukkan loyalitas terhadap pihak yang dilayani. Namun dengan demikian, auditor internal tidak boleh secara sadar terlibat dalam kegiatan-kegiatan yang menyimpang atau melanggar hukum;

3. Auditor internal tidak boleh secara sadar terlibat dalam tindakan atau kegiatan yang dapat mendiskriditkan profesi audit internal; 
4. Auditor tidak boleh menerima sesuatu dalam bentuk apapun dari karyawan, auditan, pelanggan, pemasok, ataupun dari auditi, atau patut diduga dapat mempengaruhi pertimbangan profesinya;

5. Auditor internal hanya melakukan jasa-jasa yang dapat diselesaikan dengan menggunakan kompetensi profesional yang dimilikinya;

6. Auditor internal harus mengusahakan berbagai upaya agar senantiasa memenuhi Standar Profesional Audit Internal;

7. Auditor internal harus bersikap hati-hati dan bijaksana dalam menggunakan informasi yang diperoleh dalam melaksanakan tugasnya. Auditor internal tidak boleh menggunakan informasi rahasia untuk; (1) mendapatkan keuntungan pribadi; (2) melanggar hukum; (3) menimbulkan kerugian terhadap auditi;

8. Dalam melaporkan hasil pekerjaannya, auditor internal harus mengungkapkan semua fakta penting yang diketahuinya, karena fakta yang tidak diungkapkan dapat : (1) mendistorsi laporan atas kegiatan yang direview, atau (2) menutupi adanya praktek-praktek yang melanggar hukum;

9. Auditor internal harus senantiasa meningkatkan kompetensi serta efektivitas dan kualitas pelaksanaan tugasnya. Auditor internal wajib mengikuti pendidikan profesional berkelanjutan.

Peraturan Menteri Negara Pendayagunan Aparatur Negara No.PER/04/M.PAN/03/2008 tanggal 31 Maret 2008 tentang Kede Etik Aparat Pengawasan Intern Pemerintah dinyatakan dalam standar umum audit kinerja dan audit investigasi meliputi standar-standar yang terkait dengan prinsipprinsip yang harus dipatuhi oleh auditor dalam menjalankan tugasnya. Prinsipprinsip yang dimaksud adalah integritas, objektivitas, kerahasiaan dan normanorma.

\section{Kompetensi}

Spencer (2008), mendefinisikan kompetensi sebagai karakteristik dasar dari seseorang yang biasanya terkait dengan kinerja yang efektif menurut kriteria tertentu. Kompetensi merupakan karakteristik seseorang yang terkait dengan kinerja terbaik dalam sebuah pekerjaan tertentu. Kompetensi juga dapat didefinisikan sebagai suatu karakteristik dasar individu yang memiliki hubungan kausal sebab akibat dengan kriteria yang dijadikan acuan, efektif atau berpenampilan superior ditempat kerja pada posisi tertentu. Hubungan kausal berarti bahwa kompetensi dapat menyebabkan atau digunakan untuk memprediksi seseorang yang bekerja dengan baik atau buruk yang sesuai dengan kriteria spesifik atau standar (Nursalam dan Efendi 2009). Kompetensi mencerminkan hal-hal berikut:

a) Pengetahuan, pemahaman, dan pengkajian

b) Serangkaian keterampilan kognitif, teknik psikomotor dan interpersonal

c) Kepribadian dan sikap serta perilaku

Kompetensi adalah seperangkat tindakan cerdas penuh tanggung jawab yang dimiliki seseorang sebagai syarat untuk dianggap mampu oleh masyarakat dalam melaksanakan tugas-tugas dalam bidang pekerjaan tertentu (Permenpan Nomor: 05 Tahun 2009. Lebih lanjut dijelaskan bahwa tingkat kompetensi dapat dilihat dari empat point berikut:

a) Kemampuan penguasaan ilmu dan keterampilan (Know how and know why) 
b) Kemampuan berkarya (know to do)

c) Kemampuan menyikapi dan perilaku dalam berkarya, sehingga memiliki kemandirian dalam menilai dan mengambil keputusan dengan penuh tanggung jawab

d) Kemampuan bekerja sama dalam hidup bermasyarakat dengan saling menghormati dan menghargai nilai-nilai pluralisme dankedamaian (to live together)

Arnan et.al., (2009) menjelaskan ada empat hal yang merupakan karakteristik kompetensi yaitu motif, bawaan, pengetahuan akademik dan keahlian. Motif adalah sesuatu yangsecara konsisten dipikirkan atau diinginkan oleh seseorang yang menyebabkan munculnya suatu tindakan. Motif akan mengarahkan dan menyeleksi sikap menjadi tindakan atau tujuan sehingga lain dari yang lain. Bawaan dapat berupa karakteristik fisik atau kebiasaan dalam merespon suatu situasi atau informasi tertentu.Pengetahuan merupakan kompetensi yang kompleks. Skor pada tes pengetahuan sering kali kurang bermanfaat untuk memprediksi kinerja seseorang di tempatnya bekerja karena sulitnya mengukur kebutuhan pengetahuan dan keahlian yang secara nyata digunakan dalam pekerjaan.

\section{Pengalaman Kerja}

Penggunaan pengalaman didasarkan pada asumsi bahwa tugas yang dilakukan secara berulang-ulang memberikan peluang untuk belajar melakukannya dengan yang terbaik. Pengalaman kerja seseorang menunjukkan jenis-jenis pekerjaan yang pernah dilakukan seseorang dan memberikan peluang yang lebih besar bagi seseorang untuk melakukan pekerjaan yang lebih baik. Pengalaman bekerja memberikan keterampilan kerja yang cukup namun sebaliknya, keterbatasan pengalaman mengakibatkan tingkat keterampilan yang dimiliki semakin rendah.

Menurut Bouman dan Bradley (1997) pengalaman didefinisikan sebagai lamanya waktu dalam bekerja dibidangnya, dan secara spesifik pengalaman dapat diukur dengan rentang waktu yang telah digunakan terhadap suatu pekerjaan atau tugas (job). Sedangkan, menurut Sularso dan Na'im (1999), memperlihatkan bahwa seseorang dengan lebih banyak pengalaman dalam suatu bidang memiliki lebih banyak hal yang tersimpan dalam ingatannya dan dapat mengembangkan suatu pemahaman yang baik mengenai peristiwa-peristiwa. Dengan demikian orang yang mempunyai jam terbang cukup tinggi dalam bekerja akan mempunyai banyak pengalaman dibandingkan yang mempunyai jam terbang lebih sedikit.

Pengalaman seorang auditor dapat dilihat dari jenjang jabatan dan struktur tempat auditor bekerja, lamanya auditor telah bekerja, banyaknya klien yang telah diaudit, jenis bisnis klien yang telah diaudit, keahlian yang dimiliki, serta pelatihan-pelatihan yang pernah diikuti. Pengalaman berkaitan dengan tingkat ketelitian auditor.

Menurut Tubs (1992) dalam Harhianto(2004), "auditor yang berpengalaman memiliki keunggulan dalam hal mendeteksi kesalahan, memahami kesalahan secara akurat dan mencari penyebab kesalahan". Hasilnya menunjukkan bahwa semakin berpengalaman seorang auditor, mereka semakin peka dengan kesalahan, yang 
tidak biasa dan semakin memahami hal-hal lain yang terkait dengan kesalahan yang ditemukan.

Pengalaman auditor diukur berdasarkan jenjang jabatan auditor mulai dari staff sampai ke partner, dan minimal berjabatan senior untuk membedakan tahun pengalaman, serta rata-rata tahun pengalaman 2,8 tahun (antara 2,5 sampai 3,5 tahun), sedangkan yang belum berpengalaman adalah mulai dari staff sampai dengan partner dan berjabatan kurang dari 2,5 tahun (Harhianto, 2004).

Auditor yang lebih berpengalaman akan lebih cepat tanggap dalam mendeteksi kekeliruan yang terjadi. Bertambahnya pengalaman kerja auditor juga akan meningkatkan ketelitian dalam melakukan pemeriksaan, pemeriksaan yang dilakukan dengan tingkat ketelitian yang tinggi akan menghasilkan laporan audit yang berkualitas. Pengalaman profesional auditor dapat diperoleh dari pelatihanpelatihan, pengalaman kerja seorang auditor akan mendukung keterampilan dan kecepatan dalam menyelesaikan tugas-tugasnya sehingga tingkat kesalahan akan semakin berkurang.

Pengalaman audit ditunjukkan dengan jumlah penugasan audit yang pernah dilakukan. Pengalaman seorang auditor menjadi salah satu faktor yang mempengaruhi skeptisme profesional auditor karena auditor yang lebih berpengalaman dapat mendeteksi adanya kecurangan-kecurangan pada laporan keuangan. Auditor berpengalaman lebih skeptis dibandingkan dengan auditor yang tidak berpengalaman (Ansah, 2002). Pengalaman yang dimaksudkan disini adalah pengalaman auditor dalam melakukan pemeriksaan laporan keuangan. Semakin tinggi pengalaman yang dimiliki oleh auditor maka semakin tinggi pula skeptisme profesional auditornya (Gusti dan Ali, 2008).

\section{Gambar 1 Kerangka Analisis}

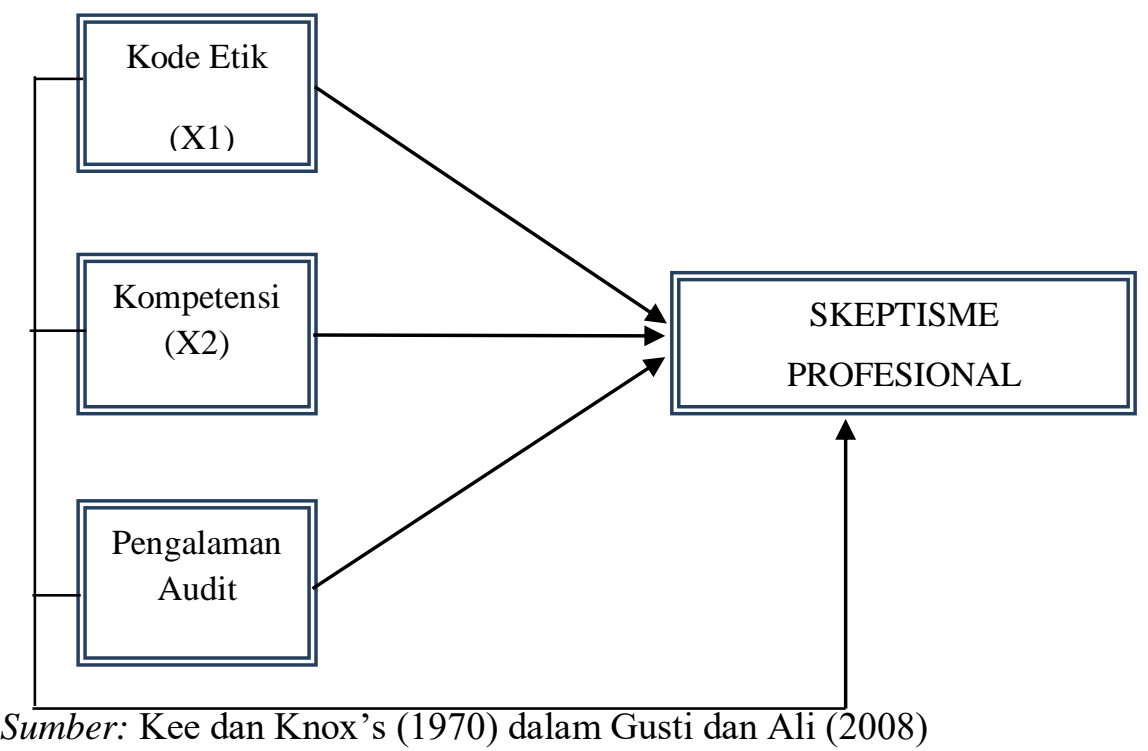




\section{Hipotesis Penelitian}

Hipotesis merupakan jawaban teoritis terhadap rumusan masalah penelitian, sebelum jawaban empiris (Sekaran, 2006:93). Jenis Hipotesis dalam penelitian ini yaitu hipotesis asosiatif, dimana dirumuskan untuk memberikan jawaban pada permasalahan yang bersifat hubungan atau pengaruh.

Skeptisme professional auditor dipengaruhi oleh kode etik, kompetensi dan pengalaman audit (Subhan, 2011). Artinya, semakin tinggi auditor menjunjung kode etik, semakin kompeten auditor melaksanakan tugas dan semakin berpengalaman auditor dalam penugasan audit, maka skeptisme auditor juga semakin tinggi.

\section{$\mathrm{H}_{\mathrm{a} 1}$ : Diduga kode etik, kompetensi dan pengalamanauditor berpengaruh terhadap skeptisme profesional auditor}

Untuk mendapatkan keseimbangan skeptisme profesional audit yang baik, seorang auditor harus taat dan tunduk kepada kode etik. Kode etik adalah seperangkat prinsip moral, prilaku, nilai, aturan atau norma-norma yang mengikat semua anggota profesinya dan ditetapkan bersama. Kode etik inilah yang mempengarui sikap skeptis profesioanl di dalam audit internal (Subhan, 2011).

$\mathrm{H}_{\mathrm{a} 2}$ : Diduga kode etik berpengaruh terhadap skeptisme profesional auditor

Kompetensiseorang auditor merupakan suatu komponen penting bagi auditor dalam melakukan prosedur audit karena kompetensi seorang auditor juga cenderung mempengaruhi tingkat skeptisme profesional auditor. Auditor harus telah menjalani pendidikan dan pelatihan teknis yang cukup dalam praktik akuntansi dan teknik auditing sehingga mampu menjalankan tugasnya dengan baik dan tepat (Arnan et al., 2009).

\section{$H_{a 3}$ : Diduga kompetensi berpengaruh terhadap skeptisme profesional auditor}

Pengalaman dapat membantu para auditor untuk menditeksi kecurangan atau penyimpangan yang dilakukan oleh auditi. Temuan-temuan yang sering dideteksi selama menjalankan tugas serta kejanggalan-kejanggalan yang sering terjadi dapat membantu auditor untuk menentukan kemana arah sikap skeptisme lebih diutamakan. Semakin banyak temuan yang pernah ditemukan selama menjalankan tugas akan semakin skeptis sikap seorang auditor terhadap klien/auditi (Ida, 2005).

\section{$\mathrm{H}_{\mathrm{a} 4}$ : Diduga pengalaman auditor berpengaruh terhadap skeptisme profesional audit}

\section{METODE PENELITIAN}

Jenis penelitian yang akan dilakukan adalah penelitian ini tergolong pada penelitian kausatif. Penelitian kausalitatif merupakan jenis penelitian yang digunakan untuk menganalisis pengaruh satu variabel dengan variabel lainnya. (Sekaran, 2006). Penelitian ini menyatakan hubungan asosiatif kasual (sebab-akibat) yaitu ada variabel independen (variabel yang mempengaruhi) dan ada variabel dependen (variabel yang dipengaruhi) (Sekaran, 2006). 
Sampel yang digunakan adalah diambil dari auditor yang bekerja pada Inspektorat Provinsi Bengkulu.Metode pengumpulan sampel yang digunakan dalam penelitian ini adalah dengan metode Sensusyaitu penentuan sampel bila semua anggota populasi digunakan sebagai sampel (Sekaran, 2006:122). Hal ini sering dilakukan bila jumlah populasi relatif kurang dari 100 orang atau penelitian yang ingin memuat generalisasi dengan kesalahan yang sangat kecil. Adapun sampel yang digunakan adalah seluruh auditor Inspektorat Provinsi Bengkulu yang berjumlah46 orang.

Analisis regresi berganda digunakan oleh peneliti, bila peneliti bermaksud meramalkan bagaimana keadaan (naik turunnya) variabel dependen, bila dua variabel atau lebih variabel independen sebagai faktor prediktor dimanipulasi (dinaik turunkan nilainya). Jadi analisi regresi ganda akan dilakukan bila jumlah variabel independennya minimal 2 (Sekaran, 2006:277), dengan rumus:

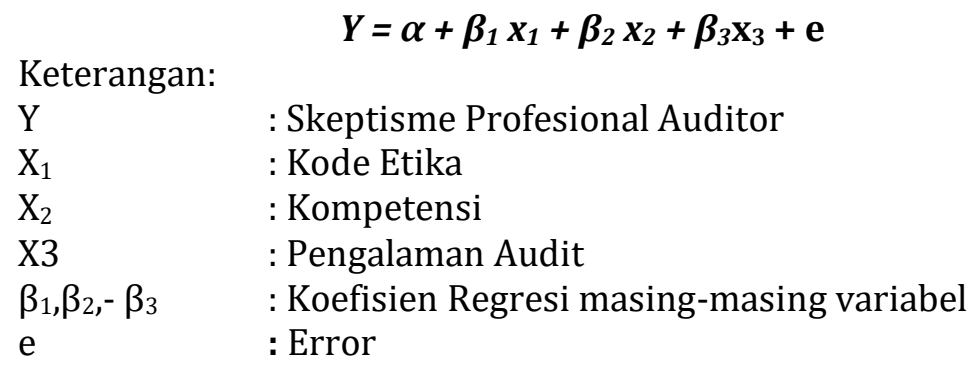

\section{HASIL PENELITIAN}

Model analisis multivariate yang digunkan dalam penelitian ini adalah analisis regresi berganda (Mutiple Regression Analysis). Variabel independen dalam penelitian ini adalah kode etik, kompetensi dan pengalaman. Sedangkan variabel dependen dalam penelitian ini adalah skeptisme professional auditor. Hasil analisis data tersebut sebagai dirangkum pada tabel berikut ini.

\section{Tabel 1}

Hasil Analisis Regresi

\begin{tabular}{|c|c|c|c|c|}
\hline \multirow[b]{2}{*}{ No } & \multirow[b]{2}{*}{ Independent Variable } & \multicolumn{2}{|c|}{ Hasil } & \multirow{2}{*}{ p-value } \\
\hline & & Coeff & t-stat & \\
\hline 1 & $\operatorname{Kode} \operatorname{Etik}\left(\mathrm{X}_{1}\right)$ & 0,416 & 4,335 & $\overline{0,000}$ \\
\hline 2 & Kompetensi $\left(\mathrm{X}_{2}\right)$ & 0,204 & 2,565 & 0,014 \\
\hline 3 & Pengalaman $\left(\mathrm{X}_{3}\right)$ & 0,418 & 3,210 & 0,003 \\
\hline \multicolumn{2}{|c|}{ Konstanta (a) } & \multicolumn{3}{|c|}{$-4,061$} \\
\hline \multicolumn{2}{|c|}{ Koefisien Korelasi Berganda (R) } & \multicolumn{2}{|r|}{0,960} & \\
\hline \multicolumn{2}{|c|}{ Koefisien Determinasi Berganda $\left(\mathrm{R}^{2}\right)$} & \multicolumn{2}{|r|}{0,921} & \\
\hline \multicolumn{2}{|c|}{ Adjusted R-Squared } & \multicolumn{2}{|r|}{0,916} & \\
\hline \multicolumn{2}{|c|}{ F-Statistic } & \multicolumn{2}{|r|}{163,613} & \\
\hline \multicolumn{2}{|c|}{ P-value (F-statistic) } & \multicolumn{2}{|r|}{0,000} & \\
\hline
\end{tabular}


Dari hasil analisis regresi tersebut diperoleh nilai koefisien korelasi berganda (R) sebesar 0,960. Hal ini berarti bahwa hubungan antara kode etik, kompetensi dan pengalaman dengan skeptisme professional auditor sangat erat. Nilai koefisien determinasi berganda (Ajusted $\mathrm{R}^{2}$ ) sebesar 0,916. Hasil ini menunjukkan bahwa variasi peningkatan atau penurunan skeptisme professional auditor dapat dijelaskan oleh variabel kode etik, kompetensi dan pengalaman sebesar 91,6\%. Sedangkan sisanya sebesar 8,4\% dijelaskan oleh faktor lain yang tidak diteliti.

\section{PEMBAHASAN}

\section{Pengaruh Kode Etik, Kompetensi dan Pengalaman terhadap Skeptisme Profesional}

Hasil penelitian menunjukkan bahwa nilai F-hitung variabel independen sebesar 163,613 dengan $p$-value sebesar 0,000. Jika nilai $p$-value tersebut dibandingkan dengan alpha 0,05, maka $p$-value $<0,05$. Hasil ini membuktikan bahwa secara bersama-sama kode etik, kompetensi dan pengalaman berpengaruh signifikan terhadap skeptisme professional auditor.

Skeptisme profesional auditor adalah sikapyang mencakup pikiran yang selalu mempertanyakan dan melakukan evaluasi secara skeptisterhadap bukti audit.Auditor dituntut untuk melaksanakan skeptisme profesionalnya sehingga auditor dapatmenggunakan kemahiran profesionalnya dengan cermat dan seksama, karena kemahiranprofesional seorang auditor mempengaruhi opini yang diberikannya. Tujuan auditor untukmemperoleh bukti kompeten yang cukup dan memberikan basis yang memadai dalam merumuskanpendapat dapat tercapai dengan baik. Dalam pelaksanaan praktik jasa auditing yang dilakukan,sebagian masyarakat masih ada yang meragukan tingkat skeptisme profesional yang dimiliki olehpara auditor yang selanjutnya berdampak pada keraguan masyarakat terhadap pemberian opini.

Kode etik audit adalah prinsip-prinsip moral professional auditor. Etika tersebut mencakup prinsip perilaku untuk para professional yang dirancang baik untuk tujuan praktis maupun tujuan idealistis. Kode etikprofessional antara lain dirancang untuk mendorong perilaku ideal, maka kode etik harus realistisdan dapat dilaksanakan. Pengembangan kesadaran etis/moral memainkan peranan kunci dalamsemua area profesi akuntan (Louwers, 1997), termasuk dalam melatih sikap skeptismeprofesional auditor.

\section{Pengaruh Kode Etik terhadap Skeptisme Profesional Auditor}

Hasil analisis deskriptif menunjukkan bahwa auditor Inspektorat Provinsi Bengkulu memiliki pemahaman yang baik mengenai kode etik profesinya. Namun dari 11 item pertanyaan yang digunakan, terdapat item pertanyaan yang memperoleh nilai rendah, yakni "saya akan mengungkapkan fakta secara benar" dengan nilai rata-rata sebesar 3,00. Perolehan nilai rata-rata identik dengan jawaban kurang. Hasil ini mengindikasikan bahwa masih ada auditor Inspektorat yang tidak mengungkapkan fakta secara benar. Hal ini terjadi karena auditor takut melakukan tindakan pemeriksaan terutama terkait dengan 'oknum birokrat' yang ada di lembaga tertentu. Kondisi ini menyebabkan auditor tidak netral dan kurang tegas, sehingga 
tidak melaksanakan pemeriksaan secara mendalam pada pelaksanaan audit sebagaimana dipersyaratkan dalam skeptisme profesionalnya.

Selanjutnya, berdasarkan hasil penelitian diketahui bahwa kode etik berpengaruh positif terhadap skeptisme auditor. Hasil ini menunjukkan bahwa kode etik yang dijunjung tinggi oleh auditor mampu membuat skeptisme professional auditor meningkat. Memang di dalam memberikan opini audit, terhadap kewajaran laporan yang diaudit seorang auditor bersikap skeptis atau ragu-ragu atau kekurangpercayaan atas laporan tersebut, sebelum melihat bukti-bukti yang melandasi/mendukung laporan tersebut.

Kode etik audit adalah prinsip-prinsip moral professional auditor. Etika tersebut mencakup prinsip perilaku untuk para professional yang dirancang baik untuk tujuan praktis maupun tujuan idealistis. Kode etikprofessional antara lain dirancang untuk mendorong perilaku ideal, maka kode etik harus realistisdan dapat dilaksanakan. Pengembangan kesadaran etis/moral memainkan peranan kunci dalamsemua area profesi akuntan (Louwers, 1997), termasuk dalam melatih sikap skeptismeprofesional auditor.

Berdasarkan teori perkembangan moral menurut Kohlberg (1981), adalah teori yangberpandangan bahwa penalaran moral merupakan dasar dari perilaku etis. Berdasarkan teori ini,auditor diharapkan dapat mentaati peraturan, etika serta ketentuan yang telah ditetapkan agarauditor menjadi lebih objektif. Auditor yang objektif adalah auditor yang mempertimbangkanbukti audit yang didapatkannya. Semakin objektif seorang auditor, maka tingkat skeptismeprofesionalnya akan semakin tinggi.

\section{Pengaruh Kompetensi terhadap Skeptisme Profesional Auditor}

Hasil analisis deskriptif pada kompetensi auditor menunjukkan bahwa auditor Inspektorat Provinsi Bengkulu memiliki kompetensi yang mendukung pelaksanaan tugas-tugasnya. Jika dilihat dari profil karakteristiknya, auditor Inspektorat telah memiliki tingkat pendidikan yang memadai (rata-rata tamat sarjana), sehingga tidak mengalami kesulitan dalam melaksanakan audit.

Hasil ini juga dibuktikan dengan pengujian hipotesis yang menunjukkan bahwa kompetensi berpengaruh positif terhadap skeptisme auditor. Hasil ini menunjukkan bahwa kompetensi yang dimiliki oleh auditor akan mendorong auditor untuk bersikap skeptis atau ragu-ragu atas laporan yang diaudit. Seorang auditor yang kompeten, tentu saja dapat mengindentifikasi apakah laporan yang diperiksa benar atau tidak, jujur atau tidak dan relevan atau tidak.

Kompetensi dan keahlian seorang auditor memiliki peran penting dalam meningkatkan skeptisme profesionalauditor. Standar umum pertama mengatur persyaratan kompetensi dan keahlian auditor dalam menjalankanprofesinya. Auditor harus telah menjalani pendidikan dan pelatihan teknis yang cukup dalampraktik akuntansi dan teknik auditing. Pendidikan formal sebagai auditor diatur dalam UU no 34tahun 1954 yang mensyaratkan akuntan publik harus menjalani pelatihan teknis yang cukup dalampraktik akuntansi dan prosedur audit. 
Pendidikan formal akuntan publik dan pelatihan teknis merupakan dua hal yang saling melengkapi (Mulyadi, 2003).

Pengawasan dan pengendalian ini tidak hanya menghasilkan laporan pemeriksaan atas laporan keuangan dan laporan keuangan yang diaudit dari BPK-RI tetapi juga memberikan catatan hasil temuan. Jika dari hasil pemeriksaan yang dilakukan oleh BPK-RI tersebut terdapat temuan, maka hal ini menjelaskan kelemahan dari pengawasan dan pengendalian internal yang dilakukan oleh Inspektorat. Oleh karena itu, untuk menjamin pelaksanaan pengawasan dan pengendalian yang tepat, dibutuhkan auditor pengawas yang memiliki kompetensi dalam bidang tugasnya.

\section{Pengaruh Pengalaman terhadap Skeptisme Profesional Auditor}

Hasil analisis deskriptif terhadap variabel pengalaman menunjukkan bahwa secara umum auditor Inspektorat Provinsi Bengkulu telah berpengalaman dalam bidang audit. Hanya saya item "lamanya waktu dalam setiap kali proses audit, menjadi pengalaman berharga dalam pelaksanaan audit mendatang" memperoleh nilai rendah sebesar 3,00. Perolehan nilai rata-rata identik dengan jawaban kurang. Hasil ini mengindikasikan bahwa masih pengalaman masa lalu tidak semata-mata digunakan sebagai acuan dalam pemberian opini audit, walaupun permasalahannya sama. Auditor tetap melaksanakan analisis bukti audit terlebih dahulu dalam pelaksanaan audit, sehingga hasilnya sesuai dengan harapan. Bagi auditor yang terburu-buru dan hanya menyandarkan pengalaman masa lalu dalam pemberian opini audit dapat dikatakan bahwa auditor tersebut memiliki skeptisme professional yang rendah.

Berdasarkan hasil penelitian diketahui bahwa pengalaman berpengaruh positif terhadap skeptisme professional auditor. Pengalaman audit ini sangat mempengaruhi skeptisme profesional auditor. Besarnya pengaruh pengalaman terhadap skeptisme professional auditor adalah 0,418.

Pengalaman dalam penugasan audit akan memperkaya pengetahuan auditor dalam bidang tugasnya. Banyaknya jenis audit yang dilakukan akan memberikan referensi auditor untuk mengambil keputusan audit di masa mendatang. Pengalaman auditor diukur berdasarkan jenjang jabatan auditor mulai dari staff sampai ke partner, dan minimal berjabatan senior untuk membedakan tahun pengalaman, serta rata-rata tahun pengalaman 2,8 tahun (antara 2,5 sampai 3,5 tahun), sedangkan yang belum berpengalaman adalah mulai dari staff sampai dengan partner dan berjabatan kurang dari 2,5 tahun (Harhianto, 2004).

Auditor yang lebih berpengalaman akan lebih cepat tanggap dalam mendeteksi kekeliruan yang terjadi. Bertambahnya pengalaman kerja auditor juga akan meningkatkan ketelitian dalam melakukan pemeriksaan, pemeriksaan yang dilakukan dengan tingkat ketelitian yang tinggi akan menghasilkan laporan audit yang berkualitas. Pengalaman profesional auditor dapat diperoleh dari pelatihanpelatihan, pengalaman kerja seorang auditor akan mendukung keterampilan dan kecepatan dalam menyelesaikan tugas-tugasnya sehingga tingkat kesalahan akan semakin berkurang. 


\section{KESIMPULAN}

Berdasarkan hasil penelitian dan pembahasan, kesimpulan yang dapat diambil adalah:

1) Kode etik, kompetensi dan pengalaman auditor berpengaruh terhadap skeptisme auditor Kantor Inspektorat Provinsi Bengkulu. Hasil ini bermakna jika semakin baik auditor dalam memahami dan melaksanakan kode etiknya, semakin baik kompetensinya dan semakin banyak pengalamannya maka skeptisme professional audit semakin meningkat.

2) Kode etik auditor berpengaruh positif terhadap skeptisme auditor Kantor Inspektorat Provinsi Bengkulu. Hasil ini bermakna jika semakin baik auditor dalam memahami dan melaksanakan kode etiknya, maka skeptisme professional auditor semakin meningkat.

3) Kompetensi auditor berpengaruh positif terhadap skeptisme auditor Kantor Inspektorat Provinsi Bengkulu. Hasil ini bermakna jika semakin tinggi dan baiknya kompetensi auditor dalam bidang audit, maka skeptisme professional audit semakin meningkat.

4) Pengalaman auditor berpengaruh positif terhadap skeptisme auditor Kantor Inspektorat Provinsi Bengkulu. Hasil ini bermakna jika semakin lama masa kerja dan semakin banyak penugasan audit oleh seorang auditor, maka skeptisme professional auditor semakin meningkat.

\section{KETERBATASAN PENELITIAN}

Penelitian ini telah dilaksanakan dengan sebaik-baiknya namun masih memiliki keterbatasan, yaitu:

1. Sampel yang digunakan hanya berasal dari satu kantor Inspektorat saja, yakni Inspektorat Provinsi Bengkulu, sehingga hasilnya tidak dapat digeneralisasi untuk kantor inspektorat yang lain. Oleh karena itu, untuk penelitian selanjutnya diharapkan adanya penambahan jumlah sampel penelitian, yang melibatkan seluruh auditor di kantor inspektorat se Provinsi Bengkulu, tetapi bisa jauh lebih luas sehingga hasilnya dapat digeneralisasi.

2. Penelitian ini tidak melakukan wawancara secara langsung terhadap responden, sehingga pengambilan kesimpulan dari penelitian ini hanya berdasarkan kuesioner saja.Untuk penelitian selanjutnya, hendaknya mempertimbangkan metode dalam pengambilan data yaitu tidak hanya dengan metode kuesioner akan tetapi dapat lebih disempurnakan dengan metode wawancara. Hal ini perlu dilakukan agar mengurangi kelemahan terkait dengan permasalahan penelitian

\section{SARAN}

Berdasarkan hasil penelitian, pembahasan, kesimpulan dan keterbatasan penelitian, maka dapat dikemukakan saran untuk penelitian selanjutnya sebagai berikut:

1. Pada variabel kode etik, upaya peningkatan yang perlu dilakukan adalah para auditor hendaknya memiliki keberanian melakukan pengungkapan fakta audit secara professional dan memadai, walaupun pada pelaksanaan audit tersebut melibatkan oknum-oknum birokrat tertentu. Hal ini diperlukan agar auditor melaksanakan kode etik dengan baik dan bertanggungjawab. Upaya yang dilakukan untuk meningkatkan pemahaman kode etik, diperlukan pembinaan dan pelatihan secara berkesinambungan sehingga auditor berkomitmen tinggi melaksanakan kode etik dan tugas-tugasnya dengan baik. 
2. Pengalaman dalam bidang audit dapat menambah kemampuan auditor dalam melaksanakan tugas. Namun, tidak semua pengalaman audit dalam bidang yang sama dapat dijadikan pedoman secara menyeluruh, auditor tetap melaksanakan pengungkapan alat bukti dan memberikan opini audit sesuai dengan kondisi factual yang terjadi saat ini. Oleh karena itu perlu pelatihan berkelanjutan, workshop-workshop bidang pemeriksaan dan sebagainya sehingga dapat meningkatkan kualitas audit.

3. Skeptisme professional auditor terutama harus dilakukan dengan melaksanakan analisis mendalam terhadap bukti audit dan temuan-temuan yang ada, sehingga opinia audit yang diberikan bersifat objektif, faktual dan dapat dipertanggungjawabkan. Diperlukan tambahan waktu bagi pelaksanaan audit sehingga auditor dapat menggali informasi lebih mendalam. Selain itu, pembinaan terhadap kemampuan auditor sangat diperlukan agar skeptisme professional meningkat. Upaya tersebut dilakukan dengan cara pemberian kesempatan kepada auditor untuk mengikuti pendidikan formal yang lebih tinggi.

4. Perlu pembagian jadwal pengawasan yang lebih efektif dengan distribusi jumlah auditor yang tepat serta pembentukan tim kerja yang solid, sehingga pelaksanaan tugas-tugas pengawasan berjalan dengan baik, efektif dan efisien. Selain itu, pemberian pembinaan yang tegas kepada auditor yang tidak melaksanakan tugas dengan baik, baik secara individu maupun kolektif. Hal ini agar kerjasama yang terjalin di dalam tim kerja berlangsung dengan baik.

\section{DAFTAR PUSTAKA}

Adrian, Arfin. (2013) Pengaruh Skeptisme Profesional, Etika, Pengalaman, Dan Keahlian Audit Terhadap Ketepatan Pemberian Opini Oleh Auditor. Jurnal Fakultas Ekonomi, Universitas Negeri Padang.

Agung, Mangaraja. (2007). "Disonansi Kognitif." Literatur. Fakultas Psikologi, Universitas Indonesia.

Ananda, Rahmatika. (2010). "Pengaruh Skeptisme Profesional, Kepatuhan pada Kode Etik dan Independensi terhadap Kualitas Audit(Studi Empiris pada BPKP perwakilan Sumatera Utara)". Jurnal Fakultas Ekonomi, Universitas Negeri Padang.

Ansah, A., 2002. Skeptisme Profesional Auditor Dan Situasi Audit, Etika, Pengalaman Serta Keahlian Audit Dengan Ketepatan Pemberian Opini Auditor Oleh Auditor. Jurnal Universitas Andalas. Padang.

Anugrah, B., 2011. Kepatuhan pada Kode Etik dan Independensi terhadap Kualitas Audit. Jurnal Fakultas Ekonomi, Universitas Negeri Padang. Tesis

Arens, Alvin, James, Loebbecke, James k. "Auditing: An Integrated Approach.8thedition.NeyJersey: Prentice -Hall.2008.

Arens, Alvins A. dan James K. Loebbecke. 2008. Auditing: Suatu Pendekatan Terpadu (judul asli: Auditing, An Integrated Approach). Penerjemah Ilham Tjakrakusuma. Jakarta:Erlangga.

Arrens. (2007). Auditing dan Pelayanan Verifikasi : Pendekatan Terpadu. Jakarta: Tim Dejacarta

Bawono, Icuk Rangga. (2010). Faktor-Faktor Dalam Diri Auditor Dan Kualitas Audit: Studi Pada Kap 'Big Four' Di Indonesia. Jurnal Akuntansi dan Auditing Indonesia Vol.14. No.2 
Bouman, Marinus J, dan Bradley Wray E (1997). Judgement and Decision Making, Part II: Expertise, Consensus and Accuracy, Behaviour Accounting Research: Fondation and Frontiers, American Accounting Association, Pg. 89 - 123

BPK RI.(2007). "Standar Pemeriksaan Keuangan Negara”. Jakarta: BPK RI. BPKP. (2008). Kode Etik dan Standar Audit. Pusdiklatwas BPKP Edisi 5

Depdiknas. (2000). Keputusan Mendiknas RI No. 232/U/2000, Tentang Pedoman Penyusunan Kurikulum Pendidikan Tinggi. Jakarta: Depdiknas

Gusti, Maghfirah dan Syahril Ali. (2008).Hubungan Skeptisme Profesional Auditor Dan Situasi Audit, Etika, Pengalaman Serta Keahlian Audit Dengan Ketepatan Pemberian Opini Auditor Oleh Auditor. Jurnal Universitas Andalas. Padang.

Handoko, TH., 2006. Manajemen Sumber Daya Manusia, BPFE, Yogyakarta

Harhinto, Teguh (2004). Pengaruh Keahlian dan Independensi terhadap Kualitas Audit Studi Empiris pada KAP di Jawa Timur. Semarang, Tesis Maksi: Universitas Dipenigoro

Herusetya, Antonius. (2007). "Kewajiban Hukum Bagi Auditor: Resiko Profesional yang Semakin Meningkat". Jurnal Akuntansi dan Keuangan. Vol.1, No.1

Ikatan Auditor Indonesia (2011). "Standar Profesional Auditor Per 1 September 2011". Cetakan Pertama.Salemba Empat. Jakarta. 2011.

Islahuzzaman. (2012). Istilah-Istilah Akuntansi dan Auditing. Bumi Aksara

Jensen, Michael C. dan W.H. Meckling. 1976. "Theory of The Firm: Managerial Behavior, Agency Cost and Ownership Structure." Journal of Financial Economics, Vol. 3, h.305-360

Louwers, Sanne (2011). Long Island University, Brooklyn Campus. Brooklyn, New York

Mardiasmo. (2002). Akuntansi Sektor Publik. Andi Yogyakarta

Mulyadi. (2003). Auditing, Edisi keenam, Cetakan pertama, Jakarta: Salemba Empat.

Narbuko, C., 2007. Ethics, Experience and Profesional Scepticism: A Situational Analysis. Behavioral Research in Accounting. Vol.8

Nasution, Hafifah. (2009). Pengaruh Beban Kerja, Pengalaman Audit Dan Tipe Kepribadian Terhadap Skeptisme Profesional Dan Kemampuan Auditor Dalam Mendeteksi Kecurangan. Jurnal Universitas Islam Negeri Syarif Hidayatullah, Jakarta

Novianti, Suzy. (2008). Skeptisme Profesional Auditor dalam Mendeteksi Kecurangan. Jurnal Ekonomi Akuntansi, Universitas Setya Kencana

Nursalam dan Efendi, 2009. Kompetensi, Pengalaman Dan Situasi Audit Terhadap Skeptisme Profesional Auditor. Jurnal Ekonomi Volume 21, Nomor 3 September 2013. Fakultas Ekonomi Universitas Riau

Quadackers. (2009). A study of auditors' skeptical characteristics and their relationship to skeptical judgments and decisions. http://hdl.handle.net/1871/13280

Sekaran, Uma. (2006). Research Methods for Business: Metodologi Penelitian untuk Bisnis. (Edisi 4). Jakarta. Salemba Empat

Shaub, M.K., Lawrence, J. E. (1996). "Ethics, Experience and Profesional Scepticism: A Situational Analysis." Behavioral Research in Accounting. Vol.8

Singgi, Santoso. (2001). Buku Pelatihan SPSS. Statistik Parametrik. Cetakan 2. Jakarta: Gramedia 
Silalahi, Sem Paulus. (2013). Pengaruh Etika, Kompetensi, Pengalaman Dan Situasi Audit Terhadap Skeptisme Profesional Auditor. Jurnal Ekonomi Volume 21, Nomor 3 September 2013. Fakultas Ekonomi Universitas Riau

Spencer LM dan Spencer SM. (2008). Competence At Work Models For Superior Performance. United States Of America: Wiley india Pvt Ltd

Subhan. (2011). "Pengaruh Kecermatan Profesi, Obyetifitas, Independensi dan Kepatuhan Pada Kode Etik Terhadap Kualitas Pemeriksaan". Madura: Jurnal Ekonomi Universitas Madura.

Sularso, S. Dan Ainun Na'im (1999). Analisis Pengaruh Pengalaman Akuntan pada Pengetahuan dan Penggunaan Intuisi dalam Mendeteksi Kekeliruan. Jurnal Riset Akuntansi Indonesia, Vol. 2 No. 2 Juli, hlm. 154-172

Suraida, Ida. (2005). "Pengaruh Etika, Kompetensi, Pengalaman Audit dan Risiko Audit terhadap Skeptisme Profesional Auditor dan Ketepatan Pemberian Opini Auditor." Sosiohumaniora. Vol.7, No.3.

Tjitridojo, Soemarjo (1980). Bunga Rampai Menuju Pemeriksaan Pengelolaan. Jakarta, PT. Ichtiar Baru, Jakarta.

Tubbs (1992). The Effect of Experience on the Auditor's Organization and Amount of Knowledge. The Accounting Review. Vol.67 No. 4 (October): 783-801.

Zulaikha (2006). Pengaruh Interaksi Gender, Kompleksitas Tugas dan Pengalaman Asuditor terhadap Audit Judgment. Simposium Nasional Akuntansi IX. Padang. 